\title{
Introduction: taking stock of the societal and legal interplay between human rights and investment
}

Yannick Radi

\section{INTRODUCTION}

As evidenced by the flow of information conveyed in the media as well as by academic literature, the interplay between human rights and investment is a key issue in today's world. This interplay has various and intertwined dimensions that this Research Handbook aims at disentangling and analysing. From a societal point of view, this interplay boils down to the impact of investment operations, conducted notably by multinational corporations (MNCs), on human rights, in particular social, economic and cultural rights. From a legal point of view, it relates to the way international law addresses the above-mentioned societal phenomenon as well as to the relationship between human rights (law) and international economic law regimes, mainly international investment law. To make sense of these various dimensions of the interplay between human rights and investment, it is necessary to shed light on their societal and legal roots and therefore to focus on the relevant facets of globalisation as well as on the pertinent features of international law.

\section{HUMAN RIGHTS AND INVESTMENT IN A GLOBALISED WORLD}

Globalisation is a complex and disputed notion. As a working definition, we can rely on this definition given by Stiglitz:

[T]he closer integration of the countries and peoples of the world which has been brought about by the enormous reduction of costs of transportation and communication, and the breaking down of artificial barriers to the free flow of 
goods, services, capital, knowledge and (to a lesser extent) people across borders. ${ }^{1}$

Globalisation is not a new phenomenon; indeed, individuals, for instance merchants or migrants, have for centuries crossed boarders to engage in a broad set of exchanges concerning 'items' as different as goods and ideas. However, this phenomenon has amplified over the second half of the twentieth century due to many factors, in particular geopolitical changes, deep technological evolutions, and the emergence of new actors, especially MNCs. ${ }^{2}$ As is evidenced by Stiglitz's definition, globalisation is a multi-faceted phenomenon. The globalisation of the economy and the globalisation of human rights are key 'facets' of this phenomenon which are often seen, in a clear-cut and passionate manner, as being either synergetic or conflictual.

\subsection{The Globalisation of the Economy}

Economic globalisation is a complex phenomenon. ${ }^{3}$ This definition provided by Cerny helps us to understand its most salient features:

It creates permissive conditions for a range of distinct but intertwined structural trends - that is, it expands the playing field within which different market actors and firms interact. It transforms the international economy from one made up of holistic national economies interacting on the basis of national 'comparative advantage' into one in which a variety of 'competitive advantages' are created in ways which are not dependent on the nation-state as social, economic, and/or political unit. ${ }^{4}$

This globalisation of the economy, in which MNCs play a key role, ${ }^{5}$ is seen by some as a chance to improve human rights conditions worldwide. For them, economic globalisation contributes positively to meet the economic preconditions which are necessary for the realisation of human

1 J Stiglitz, Globalization and its Discontents (Penguin 2002), 9-10.

2 For an historical analysis of globalisation, see eg M Steger, Globalization (4th edn, OUP 2013), ch 2.

3 See eg U Pfister, 'Globalization' (2012) European History Online available at <http://ieg-ego.eu/en/threads/backgrounds/globalization>.

4 P G Cerny, 'Globalization and Other Stories: The Search for a New Paradigm for International Relations' (1996) 51 International Journal 617, 626, cited in R McCorquodale and R Fairbrother, 'Globalization and Human Rights' (1999) 21 Human Rights Quarterly 735, 737.

5 See eg M A A Warner, 'Globalization and Human Rights: An Economic Model’ (1999) 25 Brooklyn Journal of International Law 99, 100-101. 
rights; on the contrary, others argue that the globalisation of the economy generates a harmful environment where human rights are disregarded when they collide with economic interests. ${ }^{6}$ This is considered as even more problematic as the possibility for nation-States to regulate economic globalisation is restricted by the inner features of this phenomenon, which, by definition, transcends their borders and challenges their sovereign prerogatives. ${ }^{7}$

\subsection{The Globalisation of Human Rights}

Alongside the globalisation of the economy, one can also witness the globalisation of human rights. ${ }^{8}$ This phenomenon is well explained by McCorquodale: '[T]hey [human rights] operate beyond all borders and all state mechanisms. They have become part of the discourse in almost all societies, speaking to both the elites and the oppressed, to institutions and to communities'. 9 Of course, there are on-going academic discussions as to the universality of human rights in relation to cultural relativism. ${ }^{10}$ Also the enforcement of human rights is still an issue. ${ }^{11}$ That being said, it cannot be denied that human rights have, since the end of the Second World War, gained an increasing importance in public debates, at both the international level and the domestic level. Nongovernmental organisations have played a pivotal role in this globalisation of human rights. ${ }^{12}$

6 For an account of these opinions, see eg J Westaway, 'Globalization, Transnational Corporations and Human Rights - A New Paradigm' (2012) 1(1) International Law Research 63, 64-65; R Honey, 'Impact of the Globalization of Capital on Human Righs' (2004) 60 GeoJournal 93.

7 On the impact of globalisation on sovereignty, see eg $\mathrm{J} \mathrm{Ku}$ and $\mathrm{J}$ Yoo, 'Globalization and Sovereignty' (2013) 31(1) Berkeley Journal of International Law 210.

8 See eg D Cassel, 'The Globalization of Human Rights: Consciousness, Law and Reality' (2004) 2(1) Northwestern Journal of International Human Rights 2.

9 McCorquodale and Fairbrother (n 4), 740.

10 See eg E Brems, Human Rights: Universality and Diversity (Martinus Nijhoff Publishers 2001); J Donnelly, 'Cultural Relativism and Universal Human Rights' (1984) 6(4) Human Rights Quarterly 400.

${ }_{11}$ See eg D Donoho, 'Human Rights Enforcement in the Twenty-First Century' (2006) 35(1) Georgia Journal of International and Comparative Law 1.

12 See eg C E Welch (ed), NGOs and Human Rights - Promise and Performance (Pennsylvania Press 2000). 


\section{Research handbook on human rights and investment}

The globalisation of human rights and economic globalisation have contributed together to make the interplay between human rights and investment a crucial issue in today's world. Quantitatively speaking, the globalisation of the economy has resulted of course in an increase in the impact, be it positive or negative, of investment operations on the human rights of individuals and populations. But the globalisation of human rights has greatly contributed to make this impact more visible by raising local and worldwide awareness. ${ }^{13}$ It has also led policy-makers and law-makers to tackle this issue with a view to taming the negative effects of investment operations and to make the best of their positive contribution to the promotion of human rights. ${ }^{14}$

\section{HUMAN RIGHTS AND INVESTMENT IN INTERNATIONAL LAW}

Since the end of the Second World War, international law has entered into an era of cooperation in which States have endeavoured to coordinate the exercise of their sovereignty to reach common objectives. ${ }^{15}$ Central among these objectives are the promotion and protection of human rights as well as the stimulation of economic operations. This has translated into the emergence of two regimes, respectively, international human rights law ${ }^{16}$ and international economic law. ${ }^{17}$ These two regimes mirror

13 See eg K Kolben, 'Foreign Investment and the Human Rights Link' in Amnesty International (ed), Human Rights, Trade and Investment Matters (2006), 50 available at <https://www.amnestyusa.org/files/pdfs/hrtradeinvestment matters.pdf>.

14 For an evaluation of the influence of NGOs on decision-making, see eg R Krut, 'Globalization and Civil Society: NGO Influence in International Decision-Making', United Nations Research Institute for Social Development Discussion Paper No 83 (1997) available at <www.unrisd.org/80256B3C005 BCCF9/httpNetITFramePDF?ReadForm\&parentunid=87428A38D3E0403380256 B650043B768\&parentdoctype $=$ paper\&netitpath $=80256 \mathrm{~B} 3 \mathrm{C} 005 \mathrm{BCCF} 9 /(\mathrm{httpAux}$ Pages)/87428A38D3E0403380256B650043B768/\$file/dp83.pdf>.

15 See M Friedmann, 'General Course of International Law' (1969) 127 Recueil des Cours de l'Académie de Droit International 47; P-M Dupuy, 'International Law: Torn between Coexistence, Cooperation and Globalization. General Conclusions' (1998) 9 European Journal of International Law 278.

16 See S Joseph and A McBeth (eds), Research Handbook on International Human Rights Law (Edward Elgar 2010).

17 See A T Guzman and A O Sykes (eds), Research Handbook in International Economic Law (Edward Elgar 2007). 
the globalisation of human rights and the globalisation of the economy in the legal realm. As a result, it comes as no surprise that international law adds an extra layer of complexity to the interplay between human rights and investment. To make sense of it, it is helpful - for didactic purposes - to draw a distinction between two archetypal stages that are characterised respectively by 'tension' and 'integration'.

\subsection{The Tension Between Human Rights and Investment}

Some aspects of international law have traditionally been seen as contributing to the negative impact of investment operations on human rights. This criticism relates mainly to the features of international economic law regimes, to their relationship with international human rights law as well as to the way MNCs as such are treated under international law.

The regulation of investment operations by international economic law regimes is often seen as having the potential to harm the human rights of individuals and local populations. ${ }^{18}$ Their normative features are criticised for not allowing the possibility to take into account human rights considerations or/and international human rights law. Notably, the objectives of these regimes are seen as being incompatible with the objectives of international human rights law and, more generally, the protection of human rights. For instance, the World Bank group is often criticised for not sufficiently taking into account human rights in the financing of investment projects. ${ }^{19}$ By the same token, international investment agreements are blamed for preventing the host States of foreign investors from regulating to promote and protect the human rights of their populations. ${ }^{20}$

The lack of grasp that international law has traditionally had on MNCs constitutes another dimension of the criticism formulated against international law. This criticism boils down to the traditional absence of direct obligations placed upon them in international law and in particular

\footnotetext{
18 See S Joseph, 'Human Rights and International Economic Law' (2016) European Yearbook of International Economic Law 461.

19 See eg Report of the Special Rapporteur on extreme poverty and human rights, 'Extreme Poverty and Human Rights' (4 August 2015) UN Doc A/70/274.

20 See eg S Fowles, 'How Investment Treaties Have a Chilling Effect on Human Rights' (2017) available at <www.css.ethz.ch/en/services/digital-library/ articles/article.html/419a4808-f934-4538-9359-6c4fd7b4c75a/pdf>.
} 
human rights obligations. ${ }^{21}$ In other words, international human rights law has traditionally had no direct horizontal effect; it has not been directly applicable, as a matter of international law, to MNCs and to private persons more generally. This situation is all the more challenged given that there exists an imbalance between this lack of obligation and the protection/promotion that MNCs' operations enjoy in international law. 22

With regard to these criticisms, two remarks can be formulated. First of all, it is worth making a distinction between perceptions/ misconceptions and realities; indeed, some of the criticisms formulated against international economic law regimes prove to be ill-founded. For instance, a close analysis of the application of international investment agreements by arbitration tribunals does not sustain the claim according to which international investment law and arbitration bars States from regulating to protect/promote public interests. ${ }^{23}$ In the same vein, the idea that international investment law aims only at the protection of foreign investors is erroneous; development - yesterday, economic development, and today, sustainable development - has always been a purpose assigned to this regime. ${ }^{24}$ In that sense, international investment law cannot be caricatured as being a 'foe' to international human rights law and, more generally, to human rights. ${ }^{25}$ By the same token, another reality that should be remembered is the fact that international human rights law and not only international investment law - has a role to play in the protection of investment operations; this is so because investors also have human rights which are protected, notably the right to property.

Beyond the need to focus on realities, it is worth realising that States themselves are partly responsible for the criticism formulated against

21 See eg H Aitken, 'Human Rights Obligations for the Private Sector' (2015) Right Now available at <http://rightnow.org.au/opinion-3/human-rightsobligations-for-the-private-sector/>.

22 See eg L Davarnejad, 'Strengthening the Social Dimension of International Investment Agreements by Integrating Codes of Conduct for Multinational Enterprises' Paper, OECD Global Forum on International Investment (2008) available at <www.oecd.org/investment/globalforum/40352144.pdf>.

23 See eg Y Radi, “"Much Ado About Nothing”? An Appraisal of CETA's Investment Chapter' (2017) 6(4) ESIL Reflection 1.

24 See eg Y Radi, 'International Investment Law and Development: A History of Two Concepts' in S W Schill et al. (eds), International Investment Law and Development: Bridging the Gap (Edward Elgar 2015) 69.

25 See Y Radi, "The "Human Nature" of International Investment Law' (2013) Transnational Dispute Management 1. 
international law. Indeed, the way international law has traditionally handled the interplay between human rights and investment is the product of sovereign choices geared by States' foreign policy priorities and interests. The lack of human rights obligations placed upon MNCs is highly illustrative of this matter of fact. There is no structural impediment in international law to placing such obligations upon them; the lack of legal capacity and legal personality is not an issue. Indeed, MNCs have traditionally been considered as being deprived of legal capacity and legal personality, notably because they have lacked obligations under public international law. In other words, this absence is simply a consequence and not a cause; the cause lies in particular in the reluctance that States have traditionally displayed to place upon corporations obligations which they see as an impediment to their activities. However, these policy-makers, alongside initiatives taken by international organisations, have slowly evolved in this respect and, more generally, in the regulation of the interplay between human rights and investment.

\subsection{The Integration of Human Rights and Investment}

The negative impact, whether real or perceived, of international economic law regimes on human rights as well as the globalisation of human rights have impacted policy-makers' choices; they have led them to better integrate human rights in the regulation of investment operations. This phenomenon has been amplified by the rise of sustainable development in international law ${ }^{26}$ and in international investment law in particular. ${ }^{27}$

This evolution is notably visible in newly concluded international investment agreements. For example, the drafting of those agreements, be they bilateral investment treaties or free trade agreements, leaves the possibility and even requires explicitly the taking into account of the public interest objective of States' measures, including human rights objectives. This is well evidenced by the provision of specific exceptions

26 See UNGA, 'Declaration on Environment and Development', UNGA Res 47/190 (22 December 1992) UN Doc A/ RES/47/190; UNGA, 'Declaration on the Future We Want', UNGA Res 66/288 (27 July 2012) UN Doc A/RES/66/288.

27 See eg Y Radi, 'Labour Provisions and Dispute Settlement in International Investment Agreements - An Inquiry into the Politicization of the Settlement of "Labour Disputes", (2014-2015) Yearbook on International Investment Law \& Policy 83. 
to investors' protection, in particular concerning expropriation. ${ }^{28}$ This convergence between international investment law and international human rights law can also be witnessed with regards to procedural matters; indeed, investor-state arbitration proceedings are developing features, notably a greater transparency, which are akin to the features of human rights proceedings. ${ }^{29}$ Another interesting development which evidences the evolution of international investment law consists of the various strategies used in international investment agreements with a view to making foreign investors accountable for their conduct in host States' territories. This ranges from 'corporate social responsibility' $(\mathrm{CSR})^{30}$ to civil liability in home States for the harmful conducts committed in the territory of host States. ${ }^{31}$

This latter evolution illustrates a general trend in international law towards making MNCs accountable, not only for their own conduct, but also for the conduct of their supply chains. ${ }^{32}$ This trend is made up of various strategies and it is sustained by different actors operating in

28 See for instance Comprehensive Economic and Trade Agreement between Canada and the European Union and its Member States (adopted 30 October 2016), annex 8-A available at <http://ec.europa.eu/trade/policy/in-focus/ceta/ index_en.htm>.

29 See the 2006 Revision of the ICSID Convention arbitration rules available at <https://icsid.worldbank.org/en/Pages/icsiddocs/ICSID-Convention-ArbitrationRules.aspx>; the UN Convention on Transparency in Treaty-based InvestorState Arbitration (adopted 10 December 2014, entered into force 18 October 2017) available at <www.uncitral.org/uncitral/uncitral_texts/arbitration/2014 Transparency_Convention.html>.

30 Agreement Between Canada and the Republic of Cameroon for the Promotion and Protection of Investments (adopted 3 March 2014, entered into force 16 December 2016), art 15(2) available at <http://investmentpolicyhub. unctad.org/Download/TreatyFile/3163>.

31 See eg Reciprocal Investment Promotion and Protection Agreement Between the Government of the Kingdom of Morocco and the Government of the Federal Republic of Nigeria (adopted 3 December 2016), art 20 available at $<$ http://investmentpolicyhub.unctad.org/Download/TreatyFile/5409>.

32 See notably UN Human Rights Council, 'Report of the Special Representative of the Secretary-General on the Issue of Human Rights and Transnational Corporations and other Business Enterprises, John Ruggie, Guiding Principles on Business and Human Rights: Implementing the United Nations “Protect, Respect, and Remedy" Framework' (21 March 2011) UN Doc A/HRC/ 17/31 (Ruggie report); OECD, 'OECD Due Diligence Guidance for Responsible Supply Chains of Minerals from Conflict-Affected and High-Risk Areas' (3rd edn, OECD Publishing 2016). It is worth noting that the OECD was a precursor of this trend with the adoption in 1976 of Guidelines for MNCs; see OECD, OECD Guidelines for Multinational Enterprises (OECD Publishing 2011). 
various normative systems, which all contribute to incorporating human rights considerations in the agenda and among the standards and objectives of $\mathrm{MNCs}^{33}$ It is worth noticing that MNCs themselves and international organisations, notably the United Nations, ${ }^{34}$ have taken the lead in developing this CSR culture and practice. Of course, this trend still lacks legal compulsion; ${ }^{35}$ however, all these initiatives constitute important milestones for a further integration of human rights and investment.

\section{THE ORGANISATION OF THIS RESEARCH $H A N D B O O K$}

This Research Handbook maps and provides in-depth analyses of the societal and legal dimensions of the interplay between human rights and investment sketched above. For that purpose, it is divided into three parts. Part I focuses on this interplay from the perspective of international law regimes. Part II is dedicated to the accountabilities deriving from MNCs' operations harmful for human rights. Part III provides case studies which evidence the interplay between human rights and investment in key sectors and regions.

\subsection{Part I: Views from International Law Regimes}

In Chapter 1, Kriebaum enquires into the relationship between international investment law and human rights. She focuses on situations involving allegations that the investor has violated the human rights of host States' populations and, conversely, on cases where the human rights of the investor have allegedly been violated due to States' interference with his/her investment. Chapters 2, 3 and 4 offer comparative analyses of international investment law and human rights law from a substantial and a procedural perspective. In Chapter 2, Polanco Lazo and Mella draw

33 R McCorquodale, 'Pluralism, Global Law and Human Rights: Strengthening Corporate Accountability for Human Rights Violations' (2013) 2(2) Global Constitutionalism 287.

34 In addition to the Ruggie report (n 32), see the UN Global Compact, 'What is UN Global Compact?' available at <www.unglobalcompact.org/what-is$\mathrm{gc}>$.

In the sense of the conclusion of a binding instrument, see Human Rights Council, 'Elaboration of an international legally binding instrument on transnational corporations and other business enterprises with respect to human rights' (2014) Doc No A/HRC/RES/26/9. 
parallels between the different approaches adopted by the Inter-American Court of Human Rights and investor-state arbitration tribunals in disputes that involve both foreign investment and human rights. By the same token, Fanou and Tzevelekos explore in Chapter 3 the common territory occupied by the European Convention on Human Rights and international investment law. They analyse in particular the protection granted to property under these two regimes and the limit they set on investment protection. In Chapter 4, Boisson de Chazournes and Baruti focus more generally on international human rights law and evidence the convergence between this field and international investment law with regards to transparency; these authors examine in particular the right of the public to information and participation and the acceptance of amicus curiae. Chapter 5 is dedicated to the World Trade Organization; in this chapter, Vadi analyses in particular disputes relating to cultural rights to illustrate the cases adjudicated at the WTO that have touched upon human rights. Finally, Lehane examines in Chapter 6 the role given to human rights considerations and international human rights law at the World Bank group with regards to Bank-funded investment projects. She focuses in particular on the International Bank for Reconstruction and Development and the International Development Association.

\subsection{Part II: Accountability for MNCs' Human Rights Violations}

In Chapter 7, De Brabandere and Hazelzet explore the factual and normative dimensions of international corporate responsibility for human rights violations. They also analyse existing mechanisms and new proposals aiming to enhance the accountability of MNCs, through the use of 'soft' instruments, domestic mechanisms or through self-regulatory mechanisms. Lhuilier focuses in Chapter 8 on the due diligence obligation of MNCs with regards to their 'sphere of influence'; he shows how this obligation has emerged and has been consolidated through a 'transnational legal process'. In Chapter 9, Kyriakakis analyses the debates on the international criminal responsibility of MNCs where their activities constitute, or contribute to, international crimes. She discusses the individual criminal responsibilities of private individuals as well as the controversies related to corporate duties under international criminal law. Moving the focus from MNCs to their home States, Berkes examines in Chapter 10 the home States' responsibility for the violation of their obligations under international human rights law with regard to the activities of their corporate nationals abroad. He highlights in particular a recent State practice evidencing a progressive evolution towards the home 
States' duty to offer protection from the harmful conduct of their corporate nationals acting abroad.

\subsection{Part III: Sectorial and Regional Case Studies}

In Chapter 11, Mandelbaum and Loutit enquire into the human rights impact of investments in the extractive industries. In particular, they shed light on specific aspects of extractive investments where some of the most pressing human rights abuses tend to occur - artisanal and small-scale mining, resettlement of populations, security and labour with a focus on the community level where the impacts are felt. Chapter 12 is devoted to the relationship between human rights and investment in the agricultural sector. In this chapter, Cordes unravels the general human rights issues endemic to the agricultural sector, in particular the human rights concerns associated with large-scale land acquisitions for agricultural investments. In Chapter 13, Baumann-Pauly and Jastram focus on human rights in the fashion industry. They introduce typical human rights issues that arise at different stages of the production process and they discuss selected approaches to human rights benchmarking and ranking intended to assess the human rights performance of companies in this industry. In Chapter 14, Tignino examines the relationship between private investments and the human right to water. She analyses the substantive and procedural obligations of private companies related to the right to water and the initiatives undertaken by the private sector to incorporate human rights standards in the activities of private companies. Finally, in Chapter 15 Lim explores the interplay between human rights and investment in Asia. She delves into three case studies from the South and Southeast Asian region where tensions between human rights and investments have run high. 